\title{
Forming an Effective Team in Venture Business
}

\author{
Kiselkina O.V.a \\ Yurieva O.V.b \\ Yagudin R.Kh.c \\ Valeev E.R. ${ }^{d}$ \\ abd Kazan Federal University, Institute of Management, Economics and Finance, Kazan, 420008, Russia \\ Email: hulia_k@mail.ru \\ ${ }^{\circ}$ Republican Clinical Hospital, 420064, Kazan, Orenburg tract, 138, Russia
}

\section{Doi:10.5901/mjss.2015.v6n1s3p81}

\section{Abstract}

The article explains how to create an effective venture team of venture capital projects. Problems of venture business relations between participants in the Russian economy are related to the human factor. Special relationship arose in venture business universities. Institutional and individual investors prefer to finance the company's activities with professional and proactive team of managers and specialists. To evaluate the venture capital opportunities analysis of dynamics of development of the Russian market of venture capital, defined the problems and prospects of its development.

Keywords: venture business, effective venture team, university venture business, stage venture capital, venture capital opportunities

\section{Introduction}

An important role in the innovative development of economy is venture capital. It allows you to commercialize innovative ideas, technologies and developments, create new companies and jobs, and support existing organizations. Due to this financial instrument are actively developed entire industries, such as information technology, cellular telecommunications, biotechnology, software. Many factors continue to constrain the development of the Russian venture market. Among them are those relating to the human factor: low levels of investment culture and experience of entrepreneurs, the lack of professional management team formation in venture funds, as well as researchers capable of innovative breakthroughs.

Many scientists are drawing attention to the fact that Russian developments with high innovative potential, but lacked the experience of technology commercialization in the marketplace.[6] To output the results of developments to the market need to organize the cooperation of developers and researchers with entrepreneurs and investors, build effective teams of participants in the venture process. The special relationship between the parties arose in venture business universities. It is important to understand the relationship of a business venture in the Russian economy. In the Organization of effective teamwork is useful to take into account the characteristics that affect the willingness of people to work together on investment ideas. Score of venture opportunities and analysis of the dynamics of development of the Russian market of venture capital can identify prospects.

\section{Form of Teamwork in Venture Business}

The most effective form of venture capital projects in modern conditions is teamwork, which is generally preferred when dealing with complex tasks with great uncertainty and risk. [3] It allows you to use a wide range of competencies and high-impact staff, versatile approach when selecting options to address the problems.

Team work brings together the activities of the researchers, venture managers and agents of venture capital managers. Venture capital managers provide timely transformation of ideas into product and output it to the market. With extensive knowledge in finance, personnel management and sales, they are an experienced team with the exact distribution of the works. In this command, the task of organizing the smooth operation of the parties on the basis of mutual understanding and careful positioning of participants becomes paramount. As with any team, important elements are the coherence and focus on strategic objectives, unity of motivational incentives and value orientations. [9] 
Venture business is investing in innovative projects in the early stages of the development of companies and the subsequent sharing of finance investor to share in the business. The venture can be internal and external. An internal venture is a separated Division of the enterprise organizational entities. [1] Typically, in large companies guide provides the freedom of researchers to develop and implement ideas and forming the venture team of staff from various divisions of the company. In a creative atmosphere, getting funding from corporate venture funds or trust funds, venture team is involved in the development and approval of new ideas, the transformation of innovation into a product.

Foreign venture is a legally independent entity that implements an innovative project in the field of high technology and high development of science-intensive products. Media ideas face great difficulties in establishing the venture businesses in finding the necessary human and financial resources.

Sources of innovation in most countries of the world are universities. University business venture is seen as a logical development of the scientific creativity and as a form of entrepreneurship. In the University environment, most venture capital projects start as initiative projects of universities. Subsequently they can connect interested companies. [10] The University may conduct all the research at its base alone, so later set up a company to promote research results.

The most difficult part in the venture business is to establish effective links individual researchers with those employees of the University, which will directly promote the product on the market. But it is the key process of venture business universities. The task of scientists is to report objectively to venture capital managers fact research and innovation, as the transfer of an innovative idea can be transformed or totally lost. At this stage should operate special agent specifically which communicates between the researchers and venture capital managers. [11]

In this regard, agents of venture capital managers in the team are people, tech savvy and understand what consumers are looking for a product. Studies show that any new product or technology on the market within the framework of the venture enterprise includes a substantial component of training in the use of a product or technology.

\section{Characteristics of Venture Capital Activity}

Important players in the venture capital business are investors. They are institutional investors (venture capital funds, which have attracted funds of pension funds, insurance companies, banks, corporations and through a management company investing in specific projects), corporate investors, investing in small innovative companies and then get shares in it, and business angels. In addition to granting cash, venture capitalists are heavily involved in hiring or firing the CEO of the portfolio company, choosing a board of directors, devising an overall strategy, identifying potential partners, and so on. Indeed, the researchers found that the negative affinity effect was strongest in early-stage deals, which generally require more input from investors than do later stage deals.

Business angels are highly professional in-where investors would: managers, financial advisors, consultants, academics, investing their own money in new businesses and support their community. [7] They have a more creative approach to finding projects for investment and jobs in the early stages of business development, when researchers still don't have the money to hire professional managers. Because it is difficult to document the great ideas in the business plan, business angels have to act as a Manager and to take an active part in the management of the company, to help the team in the formulation of financial and technical side of the project.

Relationship problems and investor arise from the fact that, in addressing the financial issues, the company is in the early stages of development in development planning project and often overstates the funding. Given this fact, the investor must evaluate and monitor actual financial needs and allocate funds in tranches, as their successful development. In addition, developers often overestimate the fair market value of his invention, convinced that the ideas have value in it and very expensive because of the huge cost time, financial and human resources. For venture capital is important to cash generation and their growth.

However, from the investor's point of view, the only independent value industrial design product, customers, partners, business plan and strategy for the development of the patented technology. They are taken into account when assessing the company's withdrawal from the project.

Of course, the investors prefer to finance the company's activities with professional and proactive team of managers and specialists. Among the key entrepreneurial competences for implementation of venture activity, can be described as the ability to think in a new way, discovering new business opportunities, effective communications with different partners.

Thus, the venture development is not possible without creating mutually beneficial relationships between researchers, entrepreneurs, managers and investors. They must be built on trust in any business venture, not only is the problem of the relationship.

Interesting is the study conducted by Harvard researchers.[8] They raised the following questions. What specific 
characteristics influence individuals' desire to work together on an investment deal? And given that influence, how does affinity affect investment performance?

The most important characteristics for analysis they chose ethnicity, education and employment history. Across the board, the researchers found that venture capitalists tend to coinvest in deals with other VCs who have similar characteristics. This was true regardless of whether the similarities were ability-based or affinity-based. For example, two VCs, who graduated from the same undergraduate school were 34.4 percent more likely to collaborate on a deal than were two VCs from different alma maters. And the probability of collaboration between VCs increased by 39.2 percent if they were members of the same ethnic minority group.

They found that the probability of success decreased by 17 percent if two co-investor had previously worked at the same company - even if they hadn't worked there at the same time. In cases where investors had attended the same undergraduate school, the success rate dropped to 19 percent. And, overall, the investors who were members of the same ethnic minority were 20 percent less successful than investors with different ethnic backgrounds.

Venture capital investors with similar characteristics make bad decisions because they do not take into account the views other than their own. Working groups work best when the members learn from each other's diverse experiences.

Thus, venture capitalists have a strong tendency to team up with other VCs, whose ethnic and educational backgrounds are similar to their own. Unfortunately, this trend is not always conducive to business development.

\section{Venture Opportunities and Perspectives}

An important element in the process is to identify venture capital opportunities. Opportunities in the venture business, J. Eckhardt and S. Shane is defined as a situation in which new products, services, materials, technologies or knowledge can be represented in the market by building a new relationship between the objectives and instruments of economic development.[2] Venture capital opportunities are not static monolith, they rapidly change during the venture business process. Can be very vague, but be developed in a more clearly articulated business idea and subsequently become a business with a good income.

To evaluate the venture capital opportunities in the process of business activity, will study the State and dynamics of the venture capital market in terms of its key indicators such as the volume of capital funds, the number of venture capital funds, venture capital funds investment distribution by industry and in stages.

According to the Russian venture capital Association (RVCA) in 2012 compared to 2008 year of committed investment in Russian companies increased from 1.5 billion. to 4.15 billion dollars, i.e. 240\%. According to the latest market survey RVCA for 2013 year recorded continued positive momentum on a number of significant indicators. One such indicator is the amount of accumulated in the private equity and venture capital funds. In 2013 , according to a conservative estimate that includes only the data for institutional players to the professional market, the level of capital exceeded the 28.9 billion dollars. The positive growth of the accumulated capitalized venture funds saved in recent years (19.6\% in 2011 year, 28\% in the year 2012, but only 9.6\% in 2013 year) (table 1). However, the relative growth rates remain below pre-crisis (in 2007, they accounted for $63.4 \%$, in 2008 is 39.7\%)

Table 1: Dynamics of growth of the total amount of capital venture funds in Russia

\begin{tabular}{|c|c|c|c|}
\hline \multirow{2}{*}{ Years } & \multirow{2}{*}{ The aggregate amount of capital, bln. \$. } & \multicolumn{2}{|c|}{ Change to previous year } \\
\cline { 3 - 4 } & & Abs. growth, bln. \$. & The growth rate, \% \\
\hline 2006 & 6,28 & - & - \\
\hline 2007 & 10,26 & 3,98 & 163,4 \\
\hline 2008 & 14,33 & 4,07 & 139,7 \\
\hline 2009 & 15,2 & 0,87 & 106,1 \\
\hline 2010 & 16,8 & 1,6 & 110,5 \\
\hline 2011 & 20,1 & 3,3 & 119,6 \\
\hline 2012 & 26,4 & 6,3 & 128 \\
\hline 2013 & 28,93 & 2,53 & 109,6 \\
\hline
\end{tabular}

In recent years the tendency of creating funds with a strong specialization and the emergence of the Fund focused on early stage companies. From 2008 to 2013 year number of venture funds in the Russian market increased from 80 to 200. Almost three quarters of the growth of venture capital funds (97 to 155) in 2012 year are funds from the sector of information and communication technologies (ICT). For 2013 year on the Russian market more than 45 new private 
equity and venture capital funds with a total capital of at least 2.2 billion dollars.

Business angels investment rate is very difficult due to the preference of the participants remain anonymous and hide the transactions. [5] Even in developed countries the market angels investment investing remains opaque. The amount of informal investment in 2011 in Russia amounted to about \$550 million dollars, or just over $1 \%$ of the volume of investment in the informal capital of the United States.

In the functioning of the venture capital allocated stages which correspond approximately to the stages of the life cycle of the firm or the investment. For the initial phase of the project (seed stage) are characterized by maximum risks that pose the greatest difficulty in attracting resources, but they are important for the implementation and development of breakthrough innovation. This niche market Russian venture is the least developed. Professional attachments to such stages are, as a rule, business angels. However, venture capital may be not all stages. The aggregate amount of the committed investment funds in venture stages in 2012 year accounted for about $10 \%$ of the investments in expansion, restructuring and later. Table 2 shows that the last stage of venture capital investment in Russia accounted for the majority of venture capital investments over the years of development. At this stage are often invested in company shares for sale to a strategic investor.

Table 2: The distribution of investments by stage in Russia for 2008-2012 years

\begin{tabular}{|c|c|c|c|c|c|c|c|c|c|c|}
\hline \multirow{2}{*}{ Stage } & \multicolumn{2}{|c|}{2008} & \multicolumn{2}{|c|}{2009} & \multicolumn{2}{|c|}{2010} & \multicolumn{2}{|c|}{2011} & \multicolumn{2}{|c|}{2012} \\
\hline & $\mathrm{mln} ., \$$ & $\%$ & $\mathrm{mln} ., \$$ & $\%$ & $\mathrm{mln} ., \$$ & $\%$ & $\mathrm{mln} ., \$$ & $\%$ & $\mathrm{mln} ., \$$ & $\%$ \\
\hline Seed stage & 68 & 4,6 & 13 & 2,6 & 22 & 0,9 & 129 & 4,2 & 129 & 3,1 \\
\hline Start-up & 94 & 6,4 & 110 & 21,7 & 132 & 5,2 & 143 & 4,6 & 269 & 6,5 \\
\hline Expansion, restructuring and later & 1311 & 89 & 384 & 75,6 & 2361 & 93,9 & 2811 & 91,2 & 3754 & 90,4 \\
\hline Total & 1473 & 100 & 507 & 100 & 2515 & 100 & 3083 & 100 & 4152 & 100 \\
\hline
\end{tabular}

On OECD countries have a different picture. At a later stage venture capital accounted for no more than $50 \%$ of the investment, in addition to Canada and France (fig. 1).

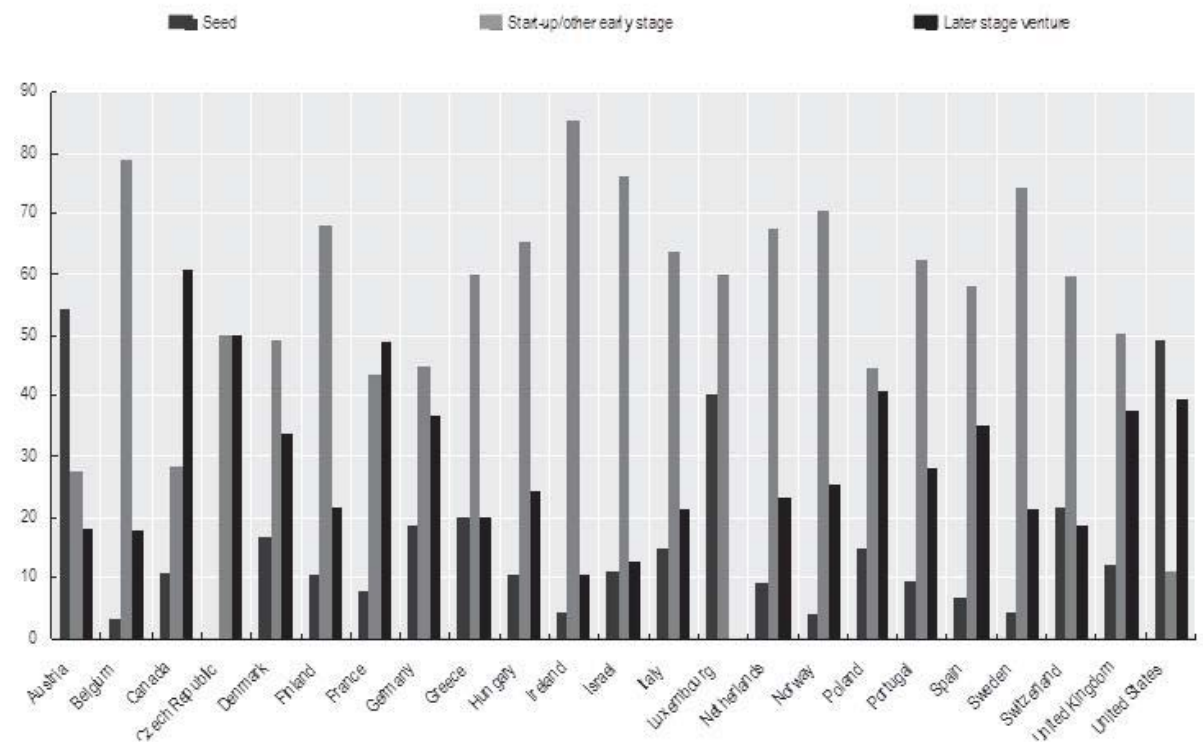

Fig. 1. Venture capital backed companies by stage (2011) [4]

Problems and prospects of development of venture activity in the Russian economy can be summarized as follows (fig.2). Sometimes it seems that knowledge generation system provides a large number of projects for which funding is not enough. In fact, the existing system of generating knowledge does not give due effect to commercial use.

To activate the venture business, big corporations should increasingly serve as a consumer innovation, create small high-tech companies and to enhance the credibility of the business. An important aspect of the venture business is compulsory activities for the protection of intellectual property through patenting. Mechanisms for the registration and 
transfer of intellectual property rights in Russia are complicated and take a long time.

The seed stage does not have the required project financing. Development of business angel investment is proceeding at a slow pace due to the lack of venture capital infrastructure to build the State must take a significant place.

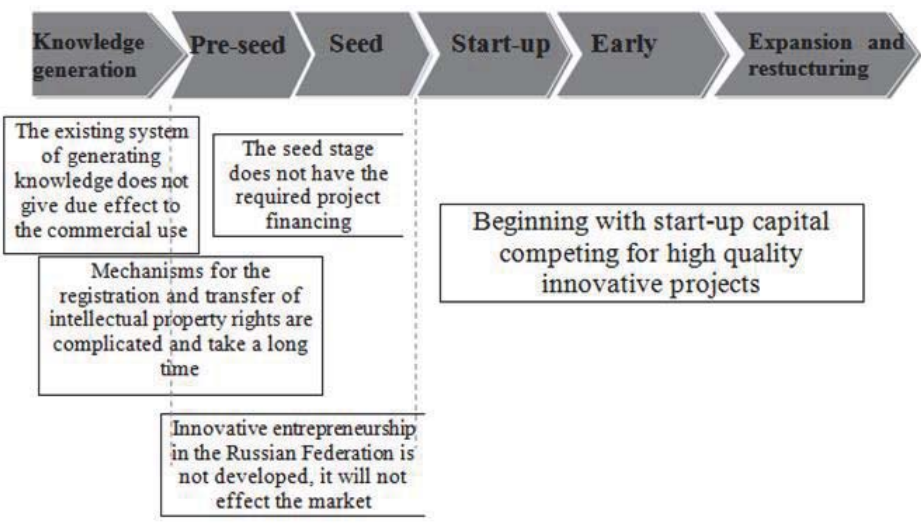

Fig. 2. The specificity of the venture business in Russia by stage

\section{Conclusions}

For the development of the venture capital market requires technology management team with a good strategy and effective cooperation and understanding of all participants in the venture business. The commercial potential of innovation depends on the field, where were identified and created. University venture business development will allow innovative breakthroughs. Universities on projects of promotion of research results and technologies in the market also contributed to the revitalization of venture business. For this purpose it is necessary to develop mechanisms to link these results with profiles of venture funds. A whole range of different in form and content organizations are practical embodiment of university relations with the business venture.

There is a lack of capital for seed and early stage companies, the majority of investments in the telecommunications industry and the Internet. Beginning with start-up capital is competing for quality innovative projects. Venture investors are looking for an experienced, credible, energetic and agile team, more than anything else. They would rather invest in a team with the idea because the team makes or stops business.

The Russian economy needs to develop entrepreneurial initiative, professionalism and communicability of participants of venture business. Implementation of venture opportunities depends on the decisions of the government on the protection of intellectual property, the creation of venture capital infrastructure.

\section{References}

Cumming D.J. Agency costs, learning and taxation in venture capital contracting // Journal of Business Venturing 20(5), 2005. pp.573622.

Eckhardt J.T., Shane S.A. Opportunities and entrepreneurship // Journal of Management 29(3), 2003. pp.333-349.

Entrepreneurship: The Engine of Growth. / Edited by Maria Minniti. London. Praeger. 2006.

Entrepreneurship at a Glance. OECD. 2013.

Fakhrutdinova, E., Mokichev, S.,Kolesnikova, J. The influence of cooperative connections on innovation activities of enterprises // World Applied Sciences Journal 27(2), 2013. pp. 48-52.

Fakhrutdinova E., Kolesnikova J., Kiselkina O., Khalikov A. Issues of commercialization of intangible property rights in Russia // World Applied Sciences Journal 27(13), 2013. pp. 48-52.

Gaglio, C.M., Katz J.A. The psychological basis of opportunity identification Entrepreneurial alertness // Small Business Economics 16(2), 2001. pp.95-111.

Gompers P., Mukhalyamov V., Xuan Y. The Cost of Friendship // NBER Working Paper No. 18141. 2012.

Hellmann, T.F., Puri M. Venture capital and the professionalization of start-up Firms: empirical evidence // Journal of Finance 57(1), 2002. pp.169-197.

Rasmussen $E$. The process of new venture creation in a university setting - University of Bodo, Norway, 2005. - P.3.

Shane S. Selling university technology: Patterns from MIT // Management Sciens 48(1). 2002. pp. 122-137. 